DOI: https://doi.org/10.33507/cakrawala.v5i1.221

\title{
Manajemen Ekstrakurikuler Seni Batik untuk Mengembangkan Potensi Diri dan Melestarikan Warisan Budaya Takbenda Indonesia
}

\author{
Erna Kartika Sari \\ Institut Pesantren Kyai Haji Abdul Chalim Mojokerto \\ 3rnakartika@gmail.com
}

\begin{abstract}
The research objectives were (1) Knowing the batik art extracurricular management strategy to develop students' self-potential. (2) Knowing the batik art extracurricular management strategy to preserve the Intangible Cultural Heritage of Indonesia for students. The type of research used is descriptive qualitative using data collection techniques through interviews, observation and documentation. The data analysis process is carried out by checking the data list, justifying the feasibility of the data and verifying the data (drawing conclusions). The validity of the data is carried out through the method of member checking, triangulation, extension of participation, persistence of observation and review of negative cases. The results of this study are (1) A well-managed and systematic batik art extracurricular management strategy can develop students' self-potential. (2) A well-managed and systematic batik art extracurricular management strategy can contribute to the preservation of Indonesia's Intangible Cultural Heritage.
\end{abstract}

Keywords : Extracurricular, Batik Arts, Development, Preservation, Intangible Cultural Heritage

\begin{abstract}
Abstrak
Tujuan penelitian adalah (1) Mengetahui strategi manajemen ekstrakurikuler seni batik untuk mengembangkan potensi diri peserta didik. (2) Mengetahui strategi manajemen ekstrakurikuler seni batik untuk melestarikan Warisan Budaya Takbenda Indonesia pada peserta didik. Jenis penelitian yang digunakan adalah kualitatif deskriptif dengan menggunakan tehnik pengumpulan data melalui wawancara, observasi dan dokumentasi. Proses analisis data dilakukan dengan mencheck list data, menjustifikasi kelayakan data dan verifikasi data (menarik kesimpulan). Keabsahan data dilakukan melalui metode member checking, triangulasi, perpanjangan keikutsertaan, ketekunan observasi dan kajian kasus negatif. Hasil Penelitian ini adalah (1) Strategi manajemen ekstrakurikuler seni batik yang dikelola dengan baik dan sistematis dapat mengembangkan potensi diri peserta didik. (2) Strategi manajemen ekstrakurikuler seni batik yang dikelola
\end{abstract}


dengan baik dan sistematis dapat memberikan kontribusi pada pelestarian Warisan Budaya Takbenda Indonesia.

\section{Kata kunci : Ekstrakurikuler, Seni Batik, Pengembangan, Pelestarian, Warisan Budaya Takbenda}

\section{PENDAHULUAN}

Pendidikan merupakan salah satu faktor yang sangat penting bagi seseorang untuk dapat meningkatkan kecerdasan, keterampilan, mengembangkan potensi diri dan dapat membentuk karakter bertanggung jawab, kreatif dan mandiri. Pada jaman dulu, sebelum ada pendidikan formal melalui sekolah seperti sekarang ini, maka pendidikan dijalankan secara spontan dan langsung dalam kehidupan sehari-hari didalam keluarga. Dengan berjalannya waktu dan jaman yang semakin berkembang, tuntutan akan ketersediaan sumber daya manusia semakin tinggi, maka kualitas yang memadai dan output yang berkualitas merupakan satu hal yang harus dihasilkan oleh sekolah sebagai satuan pendidikan formal yang tujuan dasarnya adalah menyiapkan manusia-manusia berkualitas, baik secara intelektual, integritas, maupun perannya dalam kehidupan bermasyarakat. Untuk memenuhi tuntutan ini, sekolah memiliki kegiatan intrakurikuler dan ekstrakurikuler. Dan kegiatan ekstrakurikuler yang dikelola dengan baik memberikan kontribusi yang besar untuk mencapai tujuan tersebut.

Kegiatan ekstrakurikuler yang di desain secara profesional dapat menjadi wadah yang disediakan oleh sekolah untuk menyalurkan minat, bakat, hobi, kepribadian, dan kreativitas peserta didik dan dapat dijadikan sebagai alat untuk mendeteksi potensi peserta didik. Kegiatan extrakurikuler juga dapat difungsikan sebagai salah satu program yang diselenggarakan olehsekolahsebagai solusi menghadapi perang global dan memenuhi kebutuhan dunia industrialisasi, sesuai kompetensi yang dimiliki oleh peserta didik. Hal ini diperkuat dengan beberapa hal, yaitu:

Pasal 3 Undang-Undang Nomor 20 Tahun 2003 tentang Sistem Pendidikan Nasional menyebutkan bahwa pendidikan nasional bertujuan untuk berkembangnya potensi peserta didik agar menjadi manusia yang beriman dan bertakwa kepada Tuhan Yang Maha Esa, berakhlak mulia, sehat, berilmu, cakap, kreatif, mandiri, dan menjadi warga negara yang demokratis serta bertanggung 
jawab. Pengembangan potensi peserta didik sebagaimana dimaksud dalam tujuan pendidikan nasional tersebut dapat diwujudkan melalui kegiatan ekstrakurikuler yang merupakan salah satu kegiatan dalam program kurikuler. Kegiatan ekstrakurikuler adalah program kurikuler yang alokasi waktunya tidak ditetapkan dalam kurikulum. Jelasnya bahwa kegiatan ekstrakurikuler merupakan perangkat operasional (supplement dan complements) kurikulum, yang perlu disusun dan dituangkan dalam rencana kerja tahunan/kalender pendidikan satuan pendidikan. Kegiatan ekstrakurikuler menjembatani kebutuhan perkembangan peserta didik yang berbeda; seperti perbedaan sense akan nilai moral dan sikap, kemampuan, dan kreativitas. Melalui partisipasinya dalam kegiatan ekstrakurikuler peserta didik dapat belajar dan mengembangkan kemampuan berkomunikasi, bekerja sama dengan orang lain, serta menemukan dan mengembangkan potensinya. Kegiatan ekstrakurikuler juga memberikan manfaat sosial yang besar ${ }^{1}$.

Peraturan Menteri Pendidikan Nasional Republik Indonesia No. 39 Tahun 2008 tentang Pembinaan Kesiswaan, kegiatan ekstrakurikuler adalah salah satu jalur pembinaan kesiswaan. Kegiatan ekstrakurikuler yang diikuti dan dilaksanakan oleh siswa baik di sekolah maupun di luar sekolah, bertujuan agar siswa dapat memperkaya dan memperluas diri² .

Sementara itu, tingginya jumlah lulusan SMA/MA di Jawa Timur yang tidak melanjutkan pendidikan ke perguruan tinggi berpotensi meningkatkan jumlah pengangguran baru. Tingkat Pengangguran Terbuka (TPT) berdasarkan data resmi Badan Pusat Statistik (BPS) mencapai 7,05 juta orang per Agustus 2019, dimana mengalami peningkatan dari tahun 2018. Akan tetapi secara persentase, TPT turun menjadi 5,28\% dibandingkan tahun lalu yang sebesar 5,34\%. TPT per Agustus 2019 untuk lulusan SMK mencapai 10,42\%, turun dibandingkan Agustus 2018 sebesar 11,24\%. Disusul oleh lulusan SMA sebesar $7,92 \%$ yang turun dibandingkan periode yang sama tahun lalu sebesar 7,95\%. Jadi tingkat pengangguran tertinggi masih berasal dari lulusan SMK, tetapi

\footnotetext{
${ }^{1}$ Abkin, "Lampiran III Peraturan Menteri Pendidikan Dan Kebudayaan Republik Indonesia", http://abkin.org/2019/10/download/lampiran-iii-pedoman-kegiatanekstrakurikuler.pdf, diakses 18 Maret 2020.

${ }^{2}$ Sisi Edukasi, "Permendiknas Nomor 39 Tahun 2008 Tentang Pembinaan Kesiswaan", http://berkasedukasi.com/2019/11/permendiknas-nomor-39-tahun-2008.html, diakses 15 Maret 2020.
} 
trennya mulai menurun ${ }^{3}$. Tingginya angka pengangguran dari lulusan SMK ini disebabkan tidak seimbangnya daya serap industri dengan jumlah angkatan kerja dari SMK. Selain itu banyak guru yang tidak menguasai bidang ajaran, terutama untuk mengajar ketermpilan siswa. Sebab guru-guru SMK saat ini masih banyak dari guru yang hanya menguasai ilmu murni. Untuk itu diperlukan upaya terobosan guna mencetak calon guru yang sesuai bidang, seperti pertanian, kelautan, ekonomi kreatif maupun teknologi informasi. Data yang lain menyebutkan lapangan pekerjaan yang mengalami peningkatan persentase penduduk yang bekerja terutama industri pengolahan (0,48 persen poin), konstruksi (0,46 persen poin), dan jasa lainnya (0,31 persen poin). Sebaliknya, lapangan pekerjaan yang mengalami penurunan utamanya pada pertanian, kehutanan dan perikanan (0,91 persen poin), perdagangan besar dan eceran, reparasi dan perawatan mobil dan sepeda motor $(0,41$ persen poin), dan jasa kesehatan dan kegiatan sosial ( 0,18 persen poin $)$.

Berdasarkan fakta-fakta tersebut, jika tidak mendapatkan perhatian khusus dan memperoleh interfensi dari para pemangku kebijakan, maka lulusan SMA/MA/SMK yang tidak memiliki bekal keterampilan yang memadai dan tidak pula melanjutkan pendidikan di PTN/PTS, maka akan menyumbang pada jumlah pengangguran dan akan bermuara pada kondisi Index Pembangunan Manusia (IPM) Jawa Timur.

Fokus kegiatan yang dibahas dalam jurnal ini adalah ekstrakurikuler seni batik di MA.NU Kraksaan, dimana peserta didik diharapkan mampu melakukan pengembangan-pengembangan kegiatan yang inovatif dan kreatif, memiliki daya cipta, karsa dan rasa yang tinggi serta berdaya guna untuk pengembangan potensi diri peserta didik yang mengikuti kegiatan ekstrakurikuler ini. Selanjutnya bentuk pengembangan-pengembangan tersebut disampaikan atau dikoordinasikan dengan satuan pendidikan guna dilakukan penyusunan panduan tata kelola kegiatan. Setelah melakukan pengkajian dan penyerapan aspirasi dari peserta didik, satuan pendidikan bersama-sama peserta didik melakukan sharing program kegiatan yang ditawarkan guna mendapatkan gambaran apakah program kegiatan

\footnotetext{
${ }^{3}$ Duta.Co, "Program Double Track SMA dan MA, untuk Kurangi Angak Pengangguran", http://duta.co/2019/11/22/program-double-track-sma-dan-ma-untuk-kurangi-angkapengangguran, diakses 15 Maret 2020.
} 
yang telah disusun tersebut dapat berdampak pada pengembangan potensi diri peserta didik atau tidak.

Dalam rangka pengembangan potensi diri peserta didik dan pelestarian warisan budaya takbenda Indonesia melalui kegiatan ekstrakurikuler seni batik ini, menempatkan kembali peran guru sebagai faktor sentral yang sangat berpengaruh dalam pengembangan kepribadian peserta didik. (Asmani:2012) hakikat dari seorang guru sebagai pendidik bukan hanya sebagai pengajar yang mentransfer pengetahuan yang dimilikinya kepada para peserta didik di ruang kelas, tetapi berperan juga dalam mendidik dan mengembagkan potensi dan karakter peserta didik melalui interaksi yang intensif baik itu ketika berada di dalam kelas maupun di luar kelas. ${ }^{4}$

Pendidikan karakter itu sendiri dapat dimaknai sebagai pendidikan nilai, pendidikan budi pekerti, pendidikan moral, pendidikan watak, yang bertujuan mengembangkan potensi diri peserta didik agar mampu memberikan keputusan baik buruk, memelihara apa yang baik, dan mewujudkan kebaikan itu dalam kehidupan sehari-hari dengan sepenuh hati (Samani : 2011) ${ }^{5}$.

Berdasar pada uraian konteks penelitian diatas, maka fokus penelitian yang akan dibahas dalam penelitian ini adalah: (1). Bagaimana strategi manajemen kegiatan ekstrakurikuler seni batik untuk mengembangkan potensi diri peserta didik. (2). Bagaimana strategi manajemen kegiatan ekstrakurikuler seni batik untuk melestarikan Warisan Budaya Takbenda Indonesia pada peserta didik. Sejalan dengan fokus penelitian tersebut, maka tujuan dari penelitian ini adalah: (1). Untuk mengetahui strategi manajemen kegiatan ekstrakurikuler seni batik untuk mengembangkan potensi diri peserta didik dan (2). Untuk mengetahui strategi manajemen kegiatan ekstrakurikuler seni batik untuk melestarikan Warisan Budaya Takbenda Indonesia pada peserta didik.

\footnotetext{
${ }^{4}$ Kholilurrahman, "Peran, Tugas dan Tanggung Jawab Guru, https://aliendfemmy.blogspot.com/2012/01/03/peran-tugas-dan-tanggungjawab-guru.html, diakses 15 Maret 2020.

${ }^{5}$ Muchlas Samani \& Hariyanto, Pendidikan karakter Konsep Dan Model, (Surabaya:Rosda,Cetakan 6,2017), hal.45.
} 


\section{METODOLOGI PENELITIAN}

Penelitian ini menggunakan jenis penelitian kualitatif deskriptif. Menurut Lincoln dan Guba, penelitian kualitatif adalah penelitian yang lebih menekankan pada pengungkapan makna dan proses yang merupakan hal yang emosional, latar belakang alami (natural setting) dan digunakan sebagai sumber data langsung dari peneliti sendiri sebagai instrumen kunci (Moleong, 2000:17).

Sejalan dengan definisi tersebut, Kirk dan Miller menggambarkan bahwa penelitian kualitatif adalah tradisi tertentu dalam ilmu pengetahuan sosial yang secara fundamental bergantung pada pengamatan manusia dalam kawasannya sendiri dan berhubungan dengan orang-orang tersebut dalam bahasanya dan dalam peristilahannya ( Moleong, 2000:3).

Sementara itu menurut Robert Bogdan dalam pengantar metode penelitian kualitatif dijelaskan bahwa metode kualitatif adalah prosedur penelitian yang menghasilkan data deskriptif : ucapan atau tulisan dan perilaku yang dapat diamati dari orang-orang (subyek) itu sendiri. Pendekatan ini langsung menunjukkan setting dan individu-individu dalam setting itu secara keseluruhan subyek penyelidikan, baik berupa organisasi ataupun individu, tidak dipersempit menjadi variabel yang terpisah atu menjadi hipotesis, melainkan dipandang sebagai bagian dari suatu keseluruhan ${ }^{6}$.

Dari definisi-definisi tersebut mendorong peneliti untuk melakukan penelitian kualitatif deskriptif, mengapa? karena dengan metode ini peneliti dapat mengetahui cara pandang obyek penelitian lebih mendalam yang tidak bisa diwakili dengan angka-angka statistik. Jika subyek kita ubah menjadi angkaangka statistik, makasaya akan kehilangan sifat subyektif dari perilaku manusia. Melalui metode kualitatif peneliti dapat mengenal orang (subyek) secara pribadi dan melihat mereka mengembangkan definisi mereka sendiri tentang dunia ini. Peneliti dapat merasakan apa yang mereka alami dalam pergulatan dengan masyarakat sehari-hari. Peneliti juga dapat mempelajari kelompok-kelompok dan pengalaman-pengalaman yang belum pernah peneliti ketahui sama sekali. Dalam metode kualitatif ini memungkinkan saya menyelidiki konsep-konsep yang dalam pendekatan penelitian lainnya intinya akan hilang. Konsep-konsep seperti

${ }^{6}$ Robert Bogdan dan Steven J. Taylor, Pengantar Metode Penelitian Kualitatif, 1st ed,. Terjemahan oleh Arief Furchan, (Surabaya: Usaha Nasional, 1992), 21. 
keindahan, rasa sakit, keimanan, penderitaan, frustasi, harapan dan kasih sayang dapat diselidiki sebagaimana orang-orang yang sesungguhnya dalam kehidupan mereka sehari-hari.Selain itu ada ciri-ciri khusus yang peneliti dapatkan dari penelitian kualitatif ini seperti : (1) Dalam penelitian kualitatif data dikumpulkan dalam kondisi yang asli atau alamiah (natural setting). (2) Peneliti sebagai alat penelitian, artinya peneliti sebagai alat utama pengumpul data yaitu dengan metode pengumpulan data berdasarkan pengamatan dan wawancara. (3) Dalam penelitian kualitatif diusahakan pengumpulan data secara deskriptif yang kemudian ditulis dalam laporan. Data yang diperoleh dari penelitian ini berupa kata-kata, gambar, dan bukan angka. (4) Penelitian kualitatif lebih mementingkan proses daripada hasil, artinya dalam pengumpulan data sering memperhatikan hasil dan akibat dari berbagai variabel yang saling mempengaruhi. (5) Latar belakang tingkah laku atau perbuatan dicari maknanya. Dengan demikian maka apa yang ada di balik tingkah laku manusia merupakan hal yang pokok bagi penelitian kualitatif. Mengutamakan data langsung atau "first hand". Penelitian kualitatif menuntut sebanyak mungkin kepada penelitinya untuk melakukan sendiri kegiatan penelitian di lapangan.

Dari ciri -ciri tersebut sangat memberikan peluang bagi peneliti untuk menemukan teori-teori baru yang belum pernah ditemukan oleh penelitian sebelumnya. Beberapa pendekatan yang peneliti gunakan dalam penelitian ini diantaranya : (1) Pendekatan fenomenologis, peneliti berusaha memahami arti peristiwa dan kaitan-kaitannya terhadap orang-orang biasa dalam situasi-situasi tertentu. (2) Pendekatan interaksi simbolik, diasumsikan bahwa objek orang, situasi dan peristiwa tidak memiliki pengertian sendiri, sebaliknya pengertian itu diberikan kepada mereka. Pengertian yang dlberikan orang pada pengalaman dan proses penafsirannya bersifat esensial serta menentukan. (3) Pendekatan kebudayaan, untuk menggambarkan kebudayaan menurut perspektif ini, diasumsikan peneliti memikirkan suatu peristiwa di mana manusia diharapkan berperilaku secara baik. Peneliti dengan pendekatan ini mengatakan bahwa bagaimana sebaiknya diharapkan berperilaku dalam suatu latar kebudayaan. (4) Pendekatan etnometodologi, berupaya untuk memahami bagaimana masyarakat memandang, menjelaskan dan menggambarkan tata hidup mereka sendiri. Berusaha memahami bagaimana orang-orang mulai melihat, menerangkan, dan 
menguraikan keteraturan dunia tempat mereka hidup. Peneliti dalam hal ini menerapkan sudut pandang dengan berusaha menginterpretasikan kejadian dan peristiwa sosial sesuai dari sis objek penelitiannya.

Selanjutnya, dalam penelitian ini kepekaan perasaan, kejelian dalam menangkap fenomena dan kesabaran dalam meneliti dilakukan peneliti secara berkesinambungan karena hal ini banyak memberikan masukan berarti bagi peneliti. Dalam penelitian ini peneliti berperan sebagai pengamat penuh, artinya peneliti hanya bertindak dalam pengamatan fenomena atau tingkah laku informan Dan kehadiran peneliti di lokasi penelitian diketahui statusnya sebagai peneliti oleh subjek penelitian, sehingga bisa dikatakan penelitian ini bersifat terbuka. Dengan kata lain sebelum penggalian data atau pengajuan pertanyaan-pertanyaan kepada informan dengan penggunaan metode obeservasi partisipan, wawancara mendalam, dan dokumentasi terlebih dahulu dijelaskan oleh peneliti kepada informan bahwa pertanyaan atau isian yang diajukan adalah berkaitan dengan kepentingan penelitian. Sedang masalah yang tidak kalah pentingnya adalah kehadiran peneliti di lapangan dilakukan berasaskan pada kepatuhan terhadap segala aturan dan tata tertib pihak MA.NU KRAKSAAN agar tidak mengganggu aktivitas akademik madrasah dan juga sebagai bentuk penghormatan tata aturan yang berlaku.

Kehadiran peneliti di lokasi penelitian dilakukan hampir setiap hari untuk konsultasi pada kepala madrasah, pengawas pendidikan internal madrasah, waka kesiswaan, pembina/tutor ekstrakurikuler seni batik dan staf yang terkait. Selain itu peneliti juga melakukan wawancara, observasi dan dokumentasi pada peserta didik yang mengikuti kegiatan ekstrakurikuler seni batik dengan segala macam aktivitas yang mereka lakukan. Sebagian peserta didik MA.NU KRAKSAAN dan Ketua OSIS juga menjadi subyek penelitian.

Hal menarik sebagai tantangan saat di lokasi penelitian adalah pada keadaan yang secara struktur dan sosial di lokasi penelitian tergolong beragam dan kompleks, maka upaya peneliti dalam pembangunan komunikasi di lokasi penelitan terkadang mengalami beberapa kendala, misalnya karena sibuknya informan, keengganan informan dalam memberikan data, dan terkadang terjadi kesalahpahaman komunikasi antara peneliti dengan pengelola madrasah dan 
informan. Hal tersebut menjadi penyebab dibutuhkan waktu lama untuk menunggu waktu yang tepat dan cocok.

Kehadiran peneliti di lokasi penelitian dimulai dari tanggal 4 Januari - 31 maret 2020, dengan intesitas kunjungan satu hingga tiga hari dalam tiap pekan. Agar lebih terstruktur dan terperinci, maka peneliti menyiapkan jadwal penelitian. Menurut Burhan Bungin dalam penelitian kualitatif harus ada penyiapan jadwal penelitian dan perencanaan frekuensi kehadiran peneliti dalam pengumpulan data di lokasi penelitian untuk keterkendalian penelitian.

Peneliti memilih MA.NU KRAKSAAN sebagai tempat penelitian dengan beberapa pertimbangan akademik, yaitu: (1) MA.NU KRAKSAAN adalah tempat peneliti mengabdi sebagai pendidik. Dengan melakukan penelitian kegiatan ekstrakurikuler seni batik, diharapkan hasil penelitian ini dapat memberikan kontribusi terhadap kemajuan dan berkembangnya kegiatan tersebut serta meningkatkan mutu madrasah. (2) MA.NU KRAKSAAN adalah satusatunya Madrasah Aliyah di Kabupaten Probolinggo yang memiliki kegiatan ekstrakurikuler seni batik yang dijalani secara konsisten dan mampu merambah dunia kewirausahaan. (3) Subyek penelitian yang merupakan generasi penerus bangsa merupakan hal yang sangat menarik untuk diteliti, terkait dengan minatnya terhadap seni batik. (4) Batik adalah salah satu warisan budaya tak benda yang dimiliki negara Indonesia yang harus dilestarikan eksistensinya. Hal ini menjadi daya tarik tersendiri bagi peneliti, dimana pemerintah Indonesia saat ini sedang giat menggalakkan program cinta batik Indonesia di semua sektor.

Subyek penelitian ini adalah peserta didik yang ada di MA.NU Kraksaan, khususnya peserta didik kelas X dan XI yang mengikuti kegiatan ekstrakurikuler seni batik.

Sumber data yang dipergunakan dalam penelitan ini adalah: (1) Data primer, yaitu data yang diambil dari sumber data pertama di lapangan ( Bungin, 2001:128). Data primer merupakan data yang diperoleh langsung dari tempat penelitian, yang dilakukan dengan menggunakan teknik wawancara dan pengamatan terhadap para implementor sebagai informan. Data primer penelitian ini akan digali dari Kepala Madrasah, para guru, tutor/pembina ekstrakurikuler seni batik dan peserta didik yang mengikuti kegiatan ekstrakurikuler seni batik. (2) Data sekunder, yaitu data yang diperoleh dari sumber kedua atau sumber 
sekunder (Bungin, 2001:128). Data sekunder merupakan data pendukung yang sangat diperlukan dalam penelitian ini, yang diperoleh dengan cara melakukan pencatatan terhadap dokumen-dokumen resmi yang diterbitkan oleh sekolah, dinas-dinas lain yang terkait, tulisan-tulisan maupun artikel-artikel yang menunjang penelitian ini dan juga dokumen yang berupa foto, video dan gambargambar yang mendukung penelitian ini.

Teknik pengumpulan data dalam penelitian ini melalui: (1) Wawancara (2) Observasi (3) Dokumentasi. Data dikumpulkan melalui dua proses sebagai berikut: (1) Ketika berada di lokasi penelitian (getting a long), dalam tahap ini, peneliti melakukan pengamatan langsung sehingga didapat informasi yang selengkap-lengkapnya sesuai fokus penelitian. Setelah data yang diinginkan telah terkumpul, peneliti bisa keluar dari lokasi penelitian (getting out). (2) Mengumpulkan data (logging the data), dengan cara : mengadakan wawancara, observasi dan mengumpulkan dokumen.

Data yang akan diteliti dalam kegiatan ekstrakurikuler ini diantaranya : (1) Wawancara dengan Kepala Madrasah, Pengawas Pendidikan Internal Madrasah, Waka Kesiswaan, Pembina OSIS, Pembina/Tutor Ekstrakurikuler Seni Batik dan peserta didik. (2) Mendokumentasikan setiap wawancara, observasi dan studi pustaka yang peneliti lakukan. (3) Dokumen yang dikumpulkan sebagai referensi penelitian diantaranya: Data guru dan siswa, program madrasah, sarana prasarana, daftar hadir ekstrakurikuler, jurnal ektrakurikuler, program kerja ekstrakurikuler, dokumentasi ekstrakurikuler, angket pemilihan ekstrakurikuler, buku konseling, program kerja sekolah, buku/catatan wali kelas dan guru BK dan catatan rekomendasi guru BK.

Teknik Analisis penelitian dilakukan mulai sejak awal sampai sepanjang proses penelitian berlangsung. Patton dalam Moleong (2001:103) mengatakan bahwa analisis data adalah proses mengatur urutan data, mengorganisasikannya ke dalam suatu pola, katagori dan satuan-satuan uraian dasar. Sedangkan Bogdan dan Taylor dalam Moleong (2000:103) mendefinisikan analisis data sebagai proses yang merinci usaha secara formal untuk menemukan tema dan merumuskan asumsi penelitian. Data dan informasi selanjutnya akan dimaknai dengan menggunakan analisis intepretasi sebagaimana Max Weber 
menganjurkan, yakni dengan menelusuri makna di balik fenomena yang telah diteliti.

Proses analisis data yang peneliti lakukan dalam penelitian ini: (1) Mencheck list data yang terkumpul. (2) Menjustifikasi kelayakan data yang terkumpul. (3) Mengamati dan membaca berulang-ulang catatan hasil wawancara dengan informan, apakah sudah sesuai dengan yang diharapkan atau masih diperlukan wawancara lanjutan. (4) Menguraikan variabel yang diukur secara jelas. (5) Verifikasi atau menarik kesimpulan.

Menurut Creswell, validasi temuan berarti bahwa peneliti menentukan keakuratan dan kredibilitas temuan melalui beberapa strategi, antara lain member checking. triangulasi dan auditing. Dalam penelitian ini, peneliti berusaha memastikan apakah interpretasi dan temuan penelitian akurat melalui beberapa teknik, yaitu: (1) Member checking, peneliti mengecek temuan dengan partisipan demi keakuratan temuan. Peneliti mengajukan pertanyaan pada satu atau lebih partisipan untuk tujuan seperti yang telah dijelaskan di atas. Aktivitas ini juga dilakukan untuk mengambil temuan kembali pada partisipan dan menanyakan pada mereka baik lisan maupun tertulis tentang keakuratan laporan penelitian. Pertanyaan meliputi berbagai aspek dalam penelitian, diantaranya apakah deskripsi data telah lengkap, apakah interpretasi bersifat representatif dan dilakukan tanpa kecenderungan. (2) Triangulasi, peneliti melakukan proses penyokongan bukti terhadap temuan, analisis dan interpretasi data yang telah dilakukan peneliti yang berasal dari informan, sumber data dan metode pengumpulan data. (3) Perpanjangan keikutsertaan, peneliti berada pada latar penelitian pada kurun waktu yang dianggap cukup hingga mencapai titik jenuh atas pengumpulan data di lapangan. Alasan peneliti melakukan teknik ini, yaitu untuk membangun kepercayaan informan/subjek dan kepercayaan peneliti sendiri, menghindari distorsi (kesalahan) dan mempelajari lebih dalam tentang latar dan subjek penelitian. (4) Ketekunan Observasi, peneliti mencari secara konsisten dengan berbagai cara dalam kaitan dengan proses analisis yang konstan atau tentatif dan menemukan ciri-ciri dan unsur yang relevan dengan fokus penelitian untuk lebih dicermati. Hal ini dilakukan untuk menghasilkan kedalaman penelitian yang maksimal. (5) Kajian Kasus Negatif, peneliti mengumpulkan contoh dan kasus yang tidak sesuai dengan pola dan 
kecenderungan informasi yang telah dikumpulkan dan digunakan sebagai pembanding.

\section{HASIL DAN PEMBAHASAN}

Manajemen ekstrakurikuler seni batik di MA.NU KRAKSAAN untuk mengembangkan potensi diri pada peserta didik meliputi empat tahap kegiatan: (1) Perencanaan Kegiatan. (2) Pelaksanaan Kegiatan. (3) Penilaian Kegiatan. (4) Evaluasi Kegiatan.

Perencanaan Kegiatan meliputi : (1) Membuat program kerja dengan tujuan untuk menggali potensi peserta didik di bidang seni batik, memberikan life skill (keterampilan hidup) pada peserta didik di bidang seni batik, melatih kemampuan peserta didik dibidang kewirausahaan batik, membiasakan sikap kerjasama, percaya diri, telaten, sabar dan tanggungjawab. (2) Pelaksanaan program dengan kegiatan-kegiatan yaitu berlatih membuat motif batik, melakukan proses pembuatan batik, melakukan proses packing batik yang sudah jadi, berlatih pemasaran batik, berlatih pembukuan dan melakukan pengelolaan uang kas. (3) Menyusun materi kegiatan untuk 2 semester atau satu tahun pelajaran yang terdiri dari cara membuat batik tulis, batik ciprat, batik jumputan tehnik rintang warna dan kewirausahaan batik. (4) Menyiapkan administrasi kegiatan yang terdiri dari tata tertib, daftar hadir, jurnal, daftar penilaian, buku kas anggota dan pembukuan wirausaha (buku kas, buku order, buku honorarium).

Pelaksanaan kegiatan, dimulai dengan melakukan proses seleksi pada peserta didik kelas X dan XI untuk menentukan layak atau tidak menjadi anggota ekstrakurikuler seni batik. Proses seleksi meliputi dua tahap, yaitu seleksi tulis dan lisan. Setelah proses seleksi selesai, maka kegiatan selanjutnya adalah membuat struktur organisasi. Masa periode dari pengurus organisasi seni batik di MA.NU KRAKSAAN adalah satu tahun pelajaran. Setelah itu, maka akan ditentukan lagi pengurus organisasi untuk periode selanjutnya, dengan ketentuan ketua organisasi harus dipilih dari peserta didik kelas XI yang telah memiliki pengalaman mengikuti ekstrakurikuler seni batik selama satu tahun. Anggota organisasi terdiri dari peserta didik kelas $\mathrm{X}$ dan XI yang telah melalui proses seleksi dan dinyatakan layak untuk mengikuti ekstrakurikuler seni batik. Dana operasional untuk melaksanakan kegiatan berasal dari subsidi madrasah dan kas 
anggota. Penetapan waktu dan tempat kegiatan juga dilakukan yaitu setiap hari Jum'at, jam 11.00 - 15.00 WIB. Tempat kegiatan di ruang seni dan halaman madrasah. Tata tertib kehadiran diantaranya seluruh peserta didik yang mengikuti ekstrakurikuler seni batik wajib hadir disetiap jadwal pertemuan kegiatan. Bagi peserta didik yang tidak bisa hadir diwajibkan untuk memberikan keterangan dan atau membuat surat ijin tidak hadir untuk diserahkan kepada pembina/tutor. Anggota ekstrakurikuler batik dibagi menjadi tiga kelompok, yaitu level dasar, terampil dan mahir. Dengan pembagian kelas ini, memudahkan pembina/tutor untuk membimbing dan mengarahkan target kegiatan yang harus dilakukan setiap anggota sesuai potensi atau kemampuan yang dimiliki.

Materi Kegiatan utama dari ekstrakurikuler seni batik yaitu melakukan seluruh proses pembuatan batik, yaitu batik tulis, batik ciprat dan batik jumputan tehnik rintang warna. Pada akhir semester 2 tiap tahunnya, target kegiatan adalah setiap anggota mampu membuat batik tulis karya sendiri untuk dibuat menjadi baju seragam. Proses membuat batik tulis secara berurutan adalah sebagai berikut : (1) Menggambar pola/motif batik. (2) Menjiplak pola/motif pada kain. (3) Menyanting pola/motif menggunakan malam/lilin panas. Alat yang digunakan untuk menyanting disebut canting. (4) Mewarnai pola/motif dan keseluruhan kain. (5) Mengunci warna dengan bahan kimia yaitu waterglass. (6) Melorod, yaitu proses menghilangkan malam/lilin denagn cara merebus kain di dalam air mendidih. (7) Membilas dengan air bersih untuk menghilangkan malam/lilin yang masih menempel pada kain. (8) Menjemur kain. Proses penjemuran kain batik sebaiknya di cukup diangin-anginkan saja di tempat yang teduh (tidak dibawah sinar matahari langsung). Cara ini dilakukan agar warna batik tetap awet (tidak cepat pudar). Materi kegiatan utama berikutnya yaitu belajar kewirausahaan batik, yang meliputi pengepakan (Packing), pembukuan/administrasi (administration), pemasaran (marketing). Ekstrakurikuler seni batik di MA.NU KRAKSAAN telah mampu merambah ke bidang wirausaha. Melayani pesanan kain batik dari berbagai daerah, diantaranya Surabaya, Bali, Jakarta, Palembang, Yogyakarta, Kediri dan daerah-daerah yang lain. Peserta didik mengerjakan pesanan setelah pulang sekolah hingga sore hari. Peserta didik merasa bangga karena hasil karyanya bisa diterima oleh masyarakat. Honor dari mengerjakan 
pesanan batik tersebut bisa menambah uang saku, membeli berbagai macam keperluan, membantu perekonomian orangtua dan bisa membayar uang sekolah.

Penilaian diberikan terhadap kinerja peserta didik dalam melaksanakan kegiatan ekstrakurikuler. Kriteria keberhasilan lebih ditentukan oleh proses dan keikutsertaan serta keaktifan peserta didik dalam mengikuti seluruh kegiatan ekstrakurikuler. Penilaian dilakukan secara kualitatif. Peserta didik diwajibkan untuk mendapatkan nilai minimal "baik" setiap semester. Peserta didik yang mendapatkan nilai di bawah "baik" dalam dua semester atau satu tahun, akan diberi bimbingan lebih intensif untuk mencapai nilai minimal "baik". Daftar penilaian untuk ekstrakurikuler seni batik adalah sebagai berikut :

Tabel. Daftar Penilaian Ekstrakurikuler Seni Batik

\begin{tabular}{|c|c|c|c|c|c|c|c|c|c|}
\hline \multirow[b]{2}{*}{ No } & \multirow[b]{2}{*}{ Nama } & \multirow{2}{*}{ Kls } & \multicolumn{4}{|c|}{ Penilaian Keterampilan } & \multicolumn{2}{|c|}{ Penilaian Sikap } & \multirow[b]{2}{*}{ Nilai } \\
\hline & & & $\begin{array}{l}\text { Menjiplak } \\
\end{array}$ & $\begin{array}{l}\text { Menyanting } \\
\end{array}$ & Mewarnai & Kreatifitas & Disiplin & Keaktifan & \\
\hline 1 & & & & & & & & & \\
\hline 2 & & & & & & & & & \\
\hline 3 & & & & & & & & & \\
\hline 4 & & & & & & & & & \\
\hline dst & & & & & & & & & \\
\hline
\end{tabular}

Rentang nilai $\quad: 70-79=\mathrm{C}, 80-89=\mathrm{B}, 90-100=\mathrm{A}$

Penilaian kegiatan berfungsi untuk mengetahui potensi dan kemampuan yang dimiliki oleh masing-masing peserta didik, mengetahui hasil kinerja peserta didik dan tindak lanjutnya serta menetukan peserta didik yang berhak mendapat penghargaan (reward) dari madrasah, yaitu peserta didik yang aktif dan kinerjanya memuaskan. Pihak madrasah juga memberikan sertifikat pada semua peserta didik yang telah mengikuti ekstrakurikuler dengan baik dan aktif pada saat peserta didik selesai mengikuti seluruh kegiatan, yaitu pada akhir semester 2 di kelas XI.

Evaluasi Kegiatan bertujuan untuk mengetahui kelebihan dan kekurangan program kerja dan mengetahui materi kegiatan yang paling penting, penting dan tidak penting. Evaluasi kegiatan dilakukan setiap akhir semester. Hasil dari evaluasi ini berfungsi sebagai bahan laporan kepada Kepala Madrasah dan sebagai referensi untuk membuat program kerja serta pelaksanaan kegiatan yang lebih baik di waktu selanjutnya. 
Selanjutnya manajemen ekstrakurikuler seni batik di MA.NU KRAKSAAN untuk melestarikan Warisan Budaya Takbenda Indonesia pada peserta didik meliputi 4 tahap kegiatan juga, yaitu : (1) Perencanaan Kegiatan. (2) Pelaksanaan Kegiatan. (3) Penilaian Kegiatan. (4) Evaluasi Kegiatan.

Perencanaan kegiatan meliputi : (1) Menyusun program pelatihan membatik. (1) Menyusun program kreatifitas seni batik. (3) Menyusun agenda studi banding ke lembaga lain. (4) Menyusun agenda kunjungan ke home industri batik. (5) Menyusun agenda kunjungan ke galeri batik, museum batik dan pameran batik. (6) Menyusun agenda mengikuti pameran batik. (7) Menyusun agenda mengikuti lomba dan event yang berhubungan dengan seni batik. (8) Menyusun agenda memperingati Hari batik Nasional.

Pelaksanaan kegiatan disesuaikan dengan susunan program dan agenda kegiatan yang telah disusun pada tahap perencanaan kegiatan, yang diuraikan sebagai berikut : (1) Pelatihan membatik, dilaksanakan satu kali setiap tahun pada akhir semester Pelatihan ini menjadi ilmu dan pengetahuan yang lebih luas bagi peserta didik untuk lebih memahami setiap proses membatik. Pelatihan dilakukan di tempat pengrajin batik dan komunitas seni yang berada di wilayah Kabupaten Probolinggo. Contohnya, pada tahun 2018 beberapa anggota dari club batik Syiar MANU mengikuti pelatihan membatik menggunakan malam dingin di Gunung Bromo yang diselenggarakan oleh komunitas seni Probolinggo Berkarya. (2) Kreatifitas seni batik, selain membuat batik, peserta didik diajarkan pula untuk berkreasi seni dengan tetap mengangkat tema batik, diantaranya tari batik, fashion batik, drama tentang sejarah batik, menulis dan membaca puisi, menulis cerpen, membuat motif batik klasik dan modern. (3) Studi banding ke lembaga lain, yaitu ke sekolah lain yang memiliki kegiatan ekstrakurikuler seni batik. Manfaat dari studi banding agar peserta didik memiliki barometer tentang kegiatan yang telah dilakukan. Sehingga peserta didik mengetahui kelebihan dan kekurangan dari kegiatan ekstrakurikuler yang dilakukannya. Hasil dari studi banding digunakan sebagai bahan diskusi untuk membahas hal-hal yang dirasa penting untuk diimplementasikan di kegiatan ekstrakurikuler MA.NU KRAKSAAN. (4) Kunjungan ke home industri batik, dengan tujuan untuk menambah cakrawala berpikir peserta didik tentang dunia membatik. Home industri batik yang ada di wilayah Kabupaten Probolinggo diantaranya Batik 
Dewi Rengganis, Desa Jati Urip, Kecamatan Krejengan dan Batik Ronggo Mukti, Desa Ronggo Mukti, Kecamatan Kraksaan. (5) Kunjungan ke galeri batik, museum batik dan pameran batik. Manfaat yang diperoleh peserta didik dari kunjungan ini, yaitu untuk mengetahui sejarah batik Indonesia, mengetahui berbagai macam jenis batik Indonesia, menambah wawasan tentang batik Indonesia dan menambah rasa mencintai dan menghargai batik Indonesia sebagai warisan budaya bangsa. Agenda ini dilaksanakan secara kondisional karena galeri dan museum batik letaknya di luar kota, yaitu Surabaya, Yogyakarta dan Pekalongan. Untuk mengunjungi temapt-tempat tersebut, peserta didik memerlukan waktu dan biaya yang memadai. Hal ini sering menjadi kendala untuk mewujudkannya. Pameran batik lebih sering dikunjungi oleh peserta didik karena Pemerintah Daerah kabupaten Probolinggo maupun pihak swasta sering menyelenggarakan event ini di momen-momen tertentu, seperti saat Hari Jadi Kabupaten Probolinggo, Peringatan Hari Batik nasional, HUT Dinas Pariwisata Kabupaten Probolinggo dan lain sebagainya. (6) Mengikuti pameran batik, club batik MA.NU Kraksaan telah cukup dikenal oleh instansi - instansi pemerintah Kabupaten Probolinggo, diantaranya Dinas Kesehatan, BKKBN, Kemenag dan Dinas Pariwisata. Maka dari itu, ketika instansi - instansi tersebut menyelenggarakan pameran batik, club batik MA.NU selalu diundang untuk berpartisipasi bersama dengan para pengrajin batik lain. Kegiatan ini memberikan banyak manfaat pada peserta didik, diantaranya mengetahui ragam batik khas Probolinggo, memperluas wawasan dan pengetahuan tentang batik khas Probolinggo dan melatih kemampuan berwirausaha. (7) Mengikuti lomba dan event yang berhubungan dengan seni batik diantaranya lomba dan event fashion show batik, lomba duta batik dan lomba membuat logo batik. Mengikuti berbagai kegiatan ini merupakan kebanggaan tersendiri bagi peserta didik, terlebih jika mampu menjadi pemenang lomba. Contohnya pada Hari Amal Bakti Kemenag Kabupaten Probolinggo tahun 2019, dua orang peserta didik berhasil meraih juara I dan juara III pada lomba Busana Hijab Party Batik. Di tahun 2019 juga, dua orang peserta didik berhasil menjadi 12 terbaik Duta Genre Kabupaten Probolinggo yang diselenggarakan oleh Dinas BKKBN. Dimana saat itu, dua peserta didik tersebut memakai busana batik motf tematik khas Probolinggo karya sendiri, yaitu motif Manggur (Mangga dan Anggur) dan motif Jukok Tasek 
(Ikan Laut). Club batik MA.NU juga sering diundang untuk menampilkan fashion show batik di acara - acara yang diselenggarakan oleh dinas-dinas Kabupaten Probolinggo, diantaranya Dinas Kesehatan, Dinas BKKBN, Dinas Pariwisita. Anggota club batik MA.NU juga pernah mengikuti lomba membuat logo batik yang diselenggarakan oleh Dinas Koperasi. (8) Memperingati Hari Batik Nasional pada setiap tanggal 2 Oktober. Pada momen tersebut, club batik MA.NU mengagendakan serangkaian acara dengan melibatkan seluruh peserta didik MA.NU KRAKSAAN. Beberapa kegiatan yang dilakukan, antara lain lomba membuat taplak batik jumputan tehnik rintang warna, lomba fashion show batik, lomba menghias kelas dengan ornamen batik dan lomba menggambar motif batik. Kegiatan- kegiatan ini bermanfaat untuk menambah rasa kecintaan dan penghargaan peserta didik pada batik Indonesia

Penilaian Kegiatan ditinjau dari keaktifan dan peningkatan wawasan serta pengetahuan yang dimiliki oleh peserta didik. Hasil penilaian diakumulasi denagn penilaian keterampilan masing-masing peserta didik. Penilaian kegiatan ini digunakan juga sebagai bahan diskusi dengan peserta didik setiap akhir bulan, agar peserta didik mengetahui perkembangan dan pencapaian yang telah dilakukannya.

Evaluasi Kegiatan, dilakukan oleh pembina/tutor ekstrakurikuler yang bertujuan untuk mengetahui kelebihan dan kekurangan program kunjungan dan agenda - agenda lain yang telah tersusun dalam perencanaan kegiatan serta mengetahui program kegiatan yang paling penting, penting dan tidak penting.

Berdasarkan penelitian yang telah dilakukan, peneliti menemukan temuantemuan di lapangan yang diperoleh melalui hasil wawancara, observasi dan dokumentasi . Adapun pokok-pokok temuan penelitian tersebut adalah: (1) Pengelolaan ekstrakurikuler seni batik untuk mengembangkan potensi diri peserta didik sudah dilaksanakan sesuai dengan visi misi madrasah dan program kerja yang disusun pada awal tahun pelajaran. Perencanaan kegiatan, pelaksanaan kegiatan, penilaian kegiatan dan evaluasi kegiatan dilaksanakan secara konsisten dan berkesinambungan. Meskipun ada beberapa faktor penghambat yang bermunculan selama berkegiatan, namun secara umum, ekstrakurikuler seni batik di MA.NU KRAKSAAN sudah berjalan dengan baik. Pembina/tutor yang memiliki kompetensi yang memadai di bidang seni batik serta dukungan penuh 
dari Kepala Madrasah menjadi kunci utama kegiatan ekstrakurikuler ini bisa mencapai tujuan utamanya yaitu mengembangkan potensi diri yang dimiliki oleh peserta didik di bidang seni batik. Ketika potensi peserta didik berkembang dengan baik, maka keterampilan yang mereka miliki akan menjadi salah satu modal untuk menjadi manusia yang mandiri, bermanfaat untuk diri sendiri dan orang lain. Peserta didik yang berasal dari keluarga kurang mampu dan tidak bisa melanjutkan pendidikan ke jenjang yang lebih tinggi, bisa memanfaatkan ilmu membatik yang diperoleh dari kegiatan ekstrakurikuler ini untuk bekerja di home industri batik, perusahaan - perusahaan yang bergerak di bidang konveksi, butik, bahkan bisa berwirausaha batik dan menciptakan peluang kerja bagi orang-orang disekitarnya. Hambatan atau kendala yang sering muncul adalah orangtua yang kurang mendukung jika anaknya terlalu banyak kegiatan. Hal ini mengakibatkan peserta didik tidak bisa maksimal dalam berkegiatan seni batik. Keterbatasan sarana prasarana madrasah dan kurangnya dana dari madrasah untuk mensubsidi kegiatan ekstrakurikuler seni batik juga menjadi faktor penghambat berkembangnya ekstrakurikuler ini. Tetapi pembina/tutor menegaskan, selama ada kemauan pasti ada jalan. Selama ada peluang jangan pernah dilewatkan. Prinsip ini yang pembina tularkan pada peserta didik, sehingga potensi diri peserta didik di bidang seni batik tetap bisa terakomodir dengan baik. (2) Pengelolaan ekstrakurikuler seni batik untuk melestarikan warisan budaya takbenda Indonesia pada peserta didik di MA.NU KRAKSAAN sudah dilaksanakan sesuai program kerja yang disusun pada awal tahun pelajaran. Perencanaan kegiatan, pelaksanaan kegiatan, penilaian kegiatan dan evaluasi kegiatan dilaksanakan secara konsisten dan berkesinambungan. Meskipun tidak semua program kerja bisa dilakukan, namun secara umum bisa dikatakan bahwa pihak madrasah berusaha sebaik mungkin agar tujuan pelaksanaan ekstrakurikuler seni batik yaitu untuk melestraikan warisan budaya bangsa bisa terwujud. Program kerja yang secara rutin telah dilaksanakan diantaranya adalah kunjungan ke home industri batik, pelatihan membatik dan mengikuti pameran batik. Kegiatan-kegiatan tersebut cukup mewakili tujuan dari pihak madrasah, yaitu agar peserta didik mampu mengenal berbagai macam jenis batik Indonesia, mencintai dan menghargai batik. Pembina/tutor ekstrakurikuler seni batik di MA.NU KRAKSAAN menyampaikan pada peneliti, bahwasannya ditangan 
generasi penerus bangsa lah eksistensi batik Indonesia akan terus bisa dilestarikan. Maka dari itu, mengenalkan batik, belajar membatik, menggunakan busana batik, mengunjungi galeri batik dan mengikuti pameran batik merupakan strategi jitu untuk dilaksanakan pada peserta didik. Hambatan atau kendala yang muncul disikapi optimis oleh pembina/tutor dan peserta didik yang mengikuti ekstrakurikuler seni batik ini. Salah satu peserta didik menyampaikan bahwa ia merasa senang bisa bergabung di club batik Syiar MANU. Ia menjadi lebih paham tentang batik Indonesia. Ia akan terus menekuni seni batik karena sebagai seorang remaja, ia merasa memiliki tanggung jawab akan kelestarian batik Indonesia di negeri sendiri.

\section{KESIMPULAN}

Setelah semua tahap penelitian dilakukan, mulai dari pembuatan perijinan penelitian, kemudian pengkajian teori, penyusunan instrumen penelitian yang disertai dengan uji coba dan penyempurnaan instrumen penelitian, sampai dengan pengumpulan data, pengolahan dan analisis data, pada akhirnya peneliti dapat menyimpulkan hasil penelitian sebagai berikut : (1) Manajemen ekstrakurikuler seni batik di MA.NU KRAKSAAN dalam rangka mengembangkan potensi diri peserta didik sudah dikelola dengan baik dan sistematis mulai dari perencanaan, pengorganisasian, pengkoordinasian dan pengawasan/evaluasi kegiatan, sehingga mampu memberikan kontribusi yang besar untuk mencapai tujuan utama kegiatan yaitu mengembangkan potensi diri peserta didik di MA.NU KRAKSAAN. (2) Manajemen ekstrakurikuler seni batik di MA.NU KRAKSAAN dalamrangka melestarikan warisan budaya sudah dikelola dengan cukup baik dan sistematis mulai dari perencanaan, perencanaan, pengorganisasian, pengkoordinasian dan pengawasan/evaluasi kegiatan sehingga mampu mencapai tujuan utama kegiatan berikutnya yaitu melestarikan Warisan Budaya Takbenda Indonesia pada peserta didik di MA.NU KRAKSAAN.

\section{DAFTAR PUSTAKA}

Achmad Sapari \& Hamzah, Pendidikan Karakter dan Kreativitas Guru, Solo: PT. Tiga Serangkai Pustaka Mandiri, 2012 
Ajeng Nisa Nurjanah, Manajemen Strategi dan Analisis Strategi Perusahaan, Jurnal Econisy, 2018

Edward Burnett, Primitive Culture, New York: J.P Putnam's Sons, 1971

Gerakan Literasi Nasional, Warisan Budaya Tak Benda, Artikel, Jakarta: Kementerian Pendidikan dan Kebudayaan RI

Husaini Usman, Manajemen, Jakarta: Erlangga, 2004

I Made Rustika \& Ni Made Ari Wilani, Bahan Ajar Pendekatan dalam Penelitian Kualitatif, Bali: Prodi Skilogi Fakulatas Kedokteran Universitas Udayana, 2017

Irwan Tirta, Batik sebagai Lakon, Jakarta: Gaya Favorit Press, 2009

Kartini Parmono, Nilai Kearifan Lokal Dalam Batik Tradisional Kawung, Yogyakarta: Jurnal Filsafat UGM Vol. 23, Nomor 2, 2013

Oetari Siswomihardjo, Pola Batik Klasik, Pesan Tersembunyi yang Dilupakan, Yogyakarta: Pustaka Pelajar, 2011

Peraturan Pemerintah No.10 Tahun 1993 tentang Cagar Budaya, Jakarta: Departemen Pendidikan dan Kebudayaan

Permendikbud No.106 Tahun 2013 tentang Warisan Budaya, Jakarta: Departemen Pendidikan dan Kebudayaan

Romadon Taufik, Manajemen Kegiatan Ekstrakurikuler Berbasis Pengembangan Karakter Siswa, Jurnal: Nitro Pdf Profesional, 2018

Sewan Susanto, Seni Kerajinan Batik Indonesia, Jakarta: Departemen Perindustrian RI, 1980

Undang-Undang Republik Indonesia No.11 Tahun 2010 tentang Cagar Budaya, Jakarta: Departemen Pendidikan dan Kebudayaan 